\title{
13 Return of the Good King
}

\author{
Kingship and Identity among Yushu Tibetans since $195^{1}$
}

\author{
Maria Turek
}

\begin{abstract}
This chapter focuses on history writing about the Eastern Tibetan kingdom of Nangchen based on newly published local chronicles that legitimize Nangchen as an autonomous power centre, opposing official state views on its peripherality. These historical narratives centre on an idealized concept of kingship deeply rooted in the Tibetan Buddhist orthodoxy, myth, and ritual. The contemporary remembering of the legitimate Nangchen kings' lineage transcends a revival of traditional historiography or nostalgia, and has the capacity to repair the broken connection with local tradition and to re-emphasize the value of the landscape as its container. The narrative return of the good kings becomes an important factor in the reconstruction of local identity.
\end{abstract}

Keywords: Nangchen, Qinghai, historiography, kingship, identity, revival

\section{Introduction}

The Eastern Tibetan kingdom of Nangchen, whose location today roughly corresponds to Yushu Tibetan Autonomous Prefecture (T.A.P.), Qinghai Province, remains one of the least studied Tibetan polities so far. This chapter is one of the very first attempts to draw up an ethnohistory of Nangchen by taking into consideration newly composed or republished local material.

The sources that reconstruct local history represent Nangchen as a self-referential sphere with a flourishing religious life and as being of great influence over religious culture throughout Eastern Tibet (Kham). These historiographic projects centred on 'place memory' (Casey 1987), in this example understood as a combination of local identity and a

Gros, Stéphane (ed.), Frontier Tibet: Patterns of Change in the Sino-Tibetan Borderlands. Amsterdam, Amsterdam University Press 2019

DOI: 10.5117/9789463728713_CH13 
mnemonic process, take manifold forms and may at times challenge each other. However, at the heart of a great many of these narratives lies the idealized concept of kingship, recounted through written practices that transcend factualist historiography. In post-Mao Yushu T.A.P. and for many exiled Nangchenmi ('people of Nangchen'), as the locals refer to themselves, remembering Nangchen kings re-positions the kingdom from the periphery of China or Tibet to an autonomous centre. Through and in the local narratives themselves, kingship also becomes an argument in the reconstruction of identity, which has the capacity to heal the broken connection with local tradition and, since Tibetan memory practices often evolve around specific places, to re-emphasize the value of the landscape as the container of traditional narratives. The kingship narrative proves useful in the reconstruction of identity because it re-engages with local self-description in terms of subjecthood to the Nangchen kings. A similar phenomenon has been described for another kingdom located in Kham, that of Gyelrong (Ch. Jiarong) (Prins 2007). In this contribution, I would like to draw attention to the fact that in Tibetan societies, subjecthood to a king implies belonging to a larger constellation of social and religious-mythical meanings of both pre-Buddhist and Indic Buddhist origins. These meanings provide a comprehensive explanation about the origins of and dynamics between human and non-human actors. These meanings are contained in the native place, which is very much emphasized in Tibetan culture in general. Therefore, because the cosmology of kingship is linked to the landscape and to places, the literature which resurrects this cosmology may have a profound effect on Nangchenmi in Yushu T.A.P. and in exile, and can assist them in reaffirming the ties to their homeland. The power of the kingship narrative to reconstruct local identity is especially visible in cases like Nangchen, where the king wielded little or no real political authority. The power was divided among a network of hereditary headmen with the king as primus inter pares. Above this on-the-ground structure was the sovereignty of the Qing (since at least 1725) and later, of Republican China and Qinghai warlords. However, as a sacred form of rule, the local institution of kingship was probably the most pervasive, yet symbolic, force, which determined the moral unity and local identity in the land. Parallel to several other Khampa kingdoms like Dergé and Trokyap described in this volume, kingship in Nangchen was crucial to defining its own centrality and cultural specificity. In Nangchen, this perceived autonomy was re-produced simultaneously with its marginalization by external power centres. However, these 'outer' forces were also internalized in the local kingship and power structures. This non-linear although historically consistent process is representative 
of the production of place in Kham, discussed throughout this volume, which emerges in a relational manner and which argues for a 'processual geography' of the region (Gros, this volume).

\section{Authority of the Local Narrative, Authority of the King}

As has been observed by Stevan Harrell (1995), China's government's 'civilizing project' targeted at minorities with the premise that they are in need of assistance in order to become truly civilized and fully integrated in the nation-state can lead to a reinforcement of or a focusing of ethnic identity (Harrell 1995, 27). Previous writings have also situated the memory practices of China's minorities in the context of Deng's reforms and the subsequent awakening of ethnic pride (Litzinger 1998; Harrell and Li 2003). The Tibetan minority is also engaged in negotiating their origins and pasts based on their new historiographies. The renewed interest and pride in local history can be observed throughout Kham, and the Nangchen materials discussed here should be seen against the background of this larger process.

Historians, whose work has informed this contribution, are descendants and revivers of the traditional historiographic discourse deeply rooted in Tibetan Buddhist orthodoxy and historical imagination. These native scholars therefore often position themselves differently from those who write the history of the neighbouring Dergé kingdom. Authors of the history of Dergé are employed at large Chinese universities and/ or represent an active local government and Party leadership. Their schooling has enabled them to also quote excerpts from Chinese sources on the history of Dergé. Unlike these Tibetan intellectuals, Nangchen historians are all monks, save one, Denma Jamyang Tsultrim (b. 1943). However, even the aforementioned author was trained in a traditional monastic environment. Traditional training has influenced the way these authors recollect and re-codify the past as history. This calls upon a world view dominated by religion. Perhaps as a parallel to medieval European chroniclers, who 'believed in God as being the cause of all historical processes' (Misztal 2003, 33), the Buddhist experience of history, associated with circular epochs of the rise and decline of Buddhist teachings, meant that the past and memory 'were not seen as models for understanding the present or the future but as sources of evidence of divine intervention in history' (Tosh 1991, 11-12 in Misztal 2003, 33). The opening pages of one of our Nangchen sources illustrates this orthodox view: the book begins with an image of Avalokiteśvara, the protective-deity of the Land of Snows, followed by the three dharma-kings of Tibet, then by 
images of protective deities associated with the author's clan, and finally local places said to be the abodes of those deities (Gedrong Logyü, 2-4). At the same time, we learn what constitutes an authority on this historical narrative: first, non-human beings ranked in a classic order from totally enlightened to locally bound deities and suprahuman forces associated with the local landscape. Next are photographs of an archive record and two edicts which are said to be one of the sources for the current chronicle, and lastly, a full-page photograph of the last ruling Nangchen monarch, King (gyelpo) Trashi Tséwang Dorjé (1910-1961) with the caption: 'Dharmaking Tashi Tséwang Dorjé, the sixty-seventh generation of Dru lords, and twenty-fifth in the line of kings: Photograph taken in 1950' (Gedrong Logyü, 7). The strategic position of the king directly after the divine, non-human actors and the authoritative archive materials (which include a certificate of award granted by one of the earlier kings) highlights the central theme of kingship in contemporary writings about Nangchen history. Since the revival of local and ethnic identity is simultaneous 'with the emergence of religion' (Sørensen 2015, 155) in these traditional narratives, kingship itself is viewed from a Buddhist perspective. That the genealogy of the kings is frequently recounted in the opening chapter of the local chronicles resonates with the traditional Tibetan idea about how these types of narratives serve as the universally sanctioned representation of history (Sørensen 2015, 159).

How is the revival of traditional historiography positioned within Chinese state-endorsed historical scholarship? On the one hand, China is engaged in its project of civilizing Tibetans and in writing their official historiography, for which I provide examples below. On the other hand, some Tibetan writers are in the process of negotiating this viewpoint by using practices that I will describe. However, the accounts of Tibetan history that contest the state narrative were published in the People's Republic of China (P.R.C.) by large official publishing houses. The fact that the state would endorse, or at the very least, tolerate this kind of literary production testifies to the complex relations that exist between the government's stance on history writing and the Tibetans themselves as one of China's minorities. Although these links should not be viewed in black and white, it is indeed a fact that any official scholarship about Tibetan history is expected to reflect Tibetan societies' long-standing dependency on China and on the Han as China's most advanced group. The narratives described in this chapter need to be seen against a backdrop of practices of historical appropriation, such as the notification in English, Chinese, and Tibetan that Kham's most beloved legendary hero, King Gesar of Ling and his epic story, originated 'in the highlands of Qinghai, Yushu Tibetan Autonomous Prefecture', as seen on a 
Figure 13.1 The last ruling Nangchen king, Trashi Tséwang (Topgyel) Dorjé (19101961)

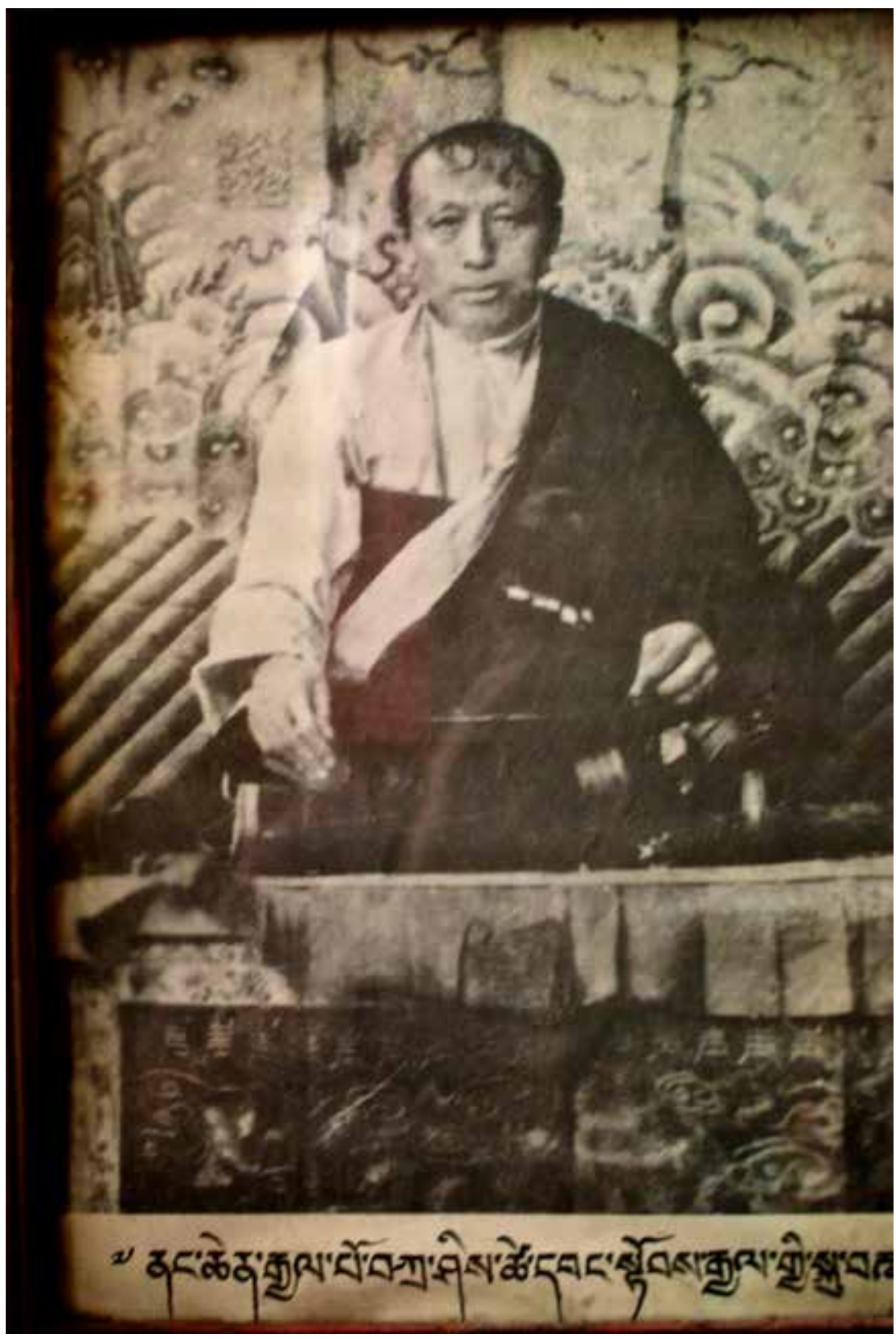

Anonymous photographer 
signpost at the recently erected Gesar monument in Jyekundo on the former territory of the Nangchen king. Khampa kingship narratives have not only been the object of appropriation but also of denigration, as evidenced by the English and Chinese renderings of the term chögyel (dharma-king) into 'headman' and 'tusi', with reference to the 42nd Dergé king, Tenpa Tsering, and inscribed on entrance tickets to the famous Dergé Printing House. Despite these examples of politics of historical representation, we might perceive the traditional Nangchen historian as engaging in the reconstruction of an alternative history in a creative effort to renegotiate their understanding of the local past with the dominant, communist and Han-centric narrative (compare Harrell and Li 2003).

KhamtöLogyü (History of Upper Kham), one of the main sources used here, opens with a black-and-white photograph of the royal family that was taken in 1951. It portrays the last, newly deposed, Nangchen king, Trashi Tséwang Dorjé with his spouse, the Dergé princess Yudrön, and their offspring in the role of envoys of the new communist regime under the watchful eye of a People's Liberation Army officer. Dressed in traditional Tibetan clothing, the king and his family are seated on a row of chairs in the centre of the photograph. The soldier is carrying a long rifle, and the sign on the concrete gate, high above their heads, reads: 'People's Government of Qinghai Province, Yushu Tibetan Autonomous Prefecture' (Khamtö Logyü II, n.pag.). Although the last ruler was granted the position of leader of the new local regime, the king was more a captive than a collaborator, and he died a decade later under house arrest. Unlike other Khampa leaders from the neighbouring Dergé: the queen regent (his own sister) and the strongman Jagö, the Nangchen king was much less proactive in the reception of the communist forces. The king's chaplain Adé Rinpoche remembers that the gyelpo initially contemplated flight into exile, but eventually settled on staying and adopted a passive attitude towards the new regime (Adeu 2011, 90).

A glance at this particular photograph reveals the stark contrast between traditional expressions of local leadership, especially in such a symbol-laden form as kingship, and the brave new order imposed from outside. This raises a number of questions about the recent local past and about how it has affected present-day ideas about belonging and identity. It also prompts the reader to think about history and its writing. When the last Nangchen gyelpo was coerced into representing the new communist power structures and, especially later, when he was not only stripped of his authority but also of his highly revered status and held in confinement, history too, in the words of Carole McGranahan (2010), was arrested. Modern Tibetan historiographies, such as Khamtö Logyü, have attempted to reverse this 
process, or at least to compensate for the crisis that arose with the abrupt rupture in the continuity of the local socio-political structure and with the erasure of its authority. By recounting Nangchen's kingship narrative, Tibetan authors from Yushu or those in exile aim to restore the kings' elevated status and fundamental role in the history of Nangchen. However, to over-write the official view of local histories that portray Eastern Tibet as backward and relevant only in its capacity as tributary to regimes ruling from China, Nangchen historians first had to reinstate the authority of the local historical narrative as a valid mode of remembering the past and thus regain control of their own history and territory.

The authors address their histories to the local elite and those exiled Nangchen Tibetans, who take interest in their past. In the new Nangchen chronicles, the power of the kings is constantly recalled, born in the reader's mind and engages with the present in ways which do not threaten the coherence of the official state narrative which presents Nangchen Tibetans as one of China's minorities. Many Tibetan authors publishing their works in China might find such an agenda too politically sensitive to express their opinion openly; but this subtle critique is reminiscent of what James Scott (1990) has called the 'hidden transcripts' practised by people of subaltern status, voicing their claims in ways that go unnoticed by power-holders.

Reviving the memory of legitimate kingship, as reflected in publications produced today in Yushu T.A.P. and among Nangchen Tibetans living abroad, compensates not only for the loss of royal authority but for what is more disruptive to local identity: the loss of recollection of this authority. Recounting elements of legitimacy formation therefore means 're-membering the dismembered' as David Germano (1998) aptly described post-Mao Tibetan revivalist practices. In the process of this revival, narratives and especially those involving secular and religious power play a vital role in effectively re-codifying local identity. The image that is recreated when Nangchen is remembered as a self-referential sphere under the revered lineage of Tibetan monarchs comprises several elements: proto-Tibetan myths and legends, the foreign mandate, and Buddhist elements such as the MahāyanāDharmaraja/Cakravartin ideal and, more specifically, the ritual power of Tantric hermitism.

\section{The Kingdom of Nangchen: A Brief History}

The territory of the historical kingdom of Nangchen was made up of a largely pastoral area surrounding the upper reaches of the Dzachu (Mekong) and 
Drichu (Yangtze) rivers. Prior to the thirteenth century Nangchen had been incorporated into the territory of the Tibetan Yarlung Empire (seventh-ninth centuries A.D.). Sometime in the mid-twelfth century the Dru clan, which claimed direct descent from one of the six ancient proto-Tibetan families, settled in Ga in what was later to become northeastern Nangchen and developed its influence over most of the Jyekundo (Yushu) area (Nangchen Gyelrap [The Royal Nangchen Chronicle], 20-21 and 32; Khamtö Logyü, 38 ). It was this very clan whose descendant would be enthroned as the first Nangchen king almost two centuries later.

By way of introducing the origins of the Dru lineage, Nangchen Gyelrap quotes the story of the matrix egg, a widespread Tibetan cosmogonic myth. It narrates how the six classes of beings hatched from the egg and then gave birth to all forms of life from which the six human clans came forth. The clans were divided into eighteen branches. Sixteen of these branches scattered in all directions. One of them was said to be the Dru. Another wellestablished mythical account in Nangchen Gyelrap, and which is repeated after Mani Kabum and other Tibetan classics, tells the story of an ogress (an emanation of Tārā) who had six children with the Monkey Meditator (who in reality was Avalokiteśvara). Their six children were the progenitors of the six clans, including the Dru (Nangchen Gyelrap, 20-22). This source also mentions specific legends involving the Dru in particular, one of which portrays early clan patriarchs as culture heroes, a cross between Yarlung emperors, a divinity and the legendary master Padmasambhava who brought Tantric Buddhism to Tibet:

Lord Dru, a divine prince with a white turban slaughtered a black, rapacious human demon, [...] and a hoard of demons headed by crab-sprits with eyes on their shoulders [...]. Lord Dru stole [from them] a bleating, conch-coloured lamb, a talking turquoise-coloured parrot and eighteen of the demon's yak bulls. In the course of a fierce battle he was the opponent of the vicious Viṣnu [...]. (Nangchen Gyelrap, 21).

Not unlike chronicles from Central Tibet, where myths and legends are intertwined with historical facts, which is particularly obvious in accounts dating back to the time of the Tibetan emperor Songtsen Gampo (seventh century), Nangchen Gyelrap (22) also describes how the Dru were of 'divine lineage'. These literary borrowings feed on a sense of timelessness and other mythic elements, a skilful technique for reconstructing both the history of the kings and also the cosmology of kingship - a necessary strategy for the successful negotiation of identity in the present revival. 
Furthermore, we learn that one of the early Dru patriarchs by the name of Kyehu Khorlo Zangpo was minister (Tib. nanglun) to an emperor, supposedly from the Tibetan Yarlung dynasty (Barom Namthar, 260-261). Nangchen Gyelrap (23-24) refers to Kyehu Khorlo Zangpo as a great (Tib. che) man. The combination of the two syllables nang and che led him to be known by the name Nangchenpa (and later prompted the name 'Nangchen' for the kingdom). As Amy Holmes-Tagchungdarpa observed in her work on another Khampa kingdom, Lhatok, historiographic techniques such as the appropriation of authority from broader Tibetan cultural narratives can highlight the autonomy and the distinctiveness of the local process, while at the same time emphasizing the sense of belonging to a larger Tibetan constellation of polities. In the case of the Nangchen royal genealogy, we find a similar process by which the format of the royal genealogy 'presents an alternative way to write and understand history as a political tool to create physical and imaginative boundaries around a place' (Holmes-Tagchungdarpa 2010, 19). In this way the narrative itself acquires historical legitimacy since it is based on another account which is seen locally as authoritative. Consequently, a narrative that has been renegotiated as history can be used as a proclamation of political power.

The following passages briefly recount the local story of state formation, governance, and the situation inside the kingdom. They are useful in our discussion about remembering kingship in Nangchen because they allow us to appreciate the complexity of the canvas onto which local historians placed kingship as a social practice.

Making reference to former places of power can be a way of capitalizing on knowledge about the landscape in order to reassert local identity and to position the native place vis-à-vis practices of peripheralization. Our sources frequently recall the earliest power centre in what was to become Nangchen - the Barom Kagyüpa monastery of Kumbum, known as 'Barom root'. Kumbum was founded by the Tangut master Repa Karpo (1198-1262), a disciple of the Tibetan imperial preceptor at the Tangut court, Tishi Repa Sherap Senggé (1164-1236). Around 1240, a few years after Tishi Repa's death, during a reconnaissance expedition under commander Doorda that Gengghis Khan's grandson Godan Khan had dispatched to conquer Tibetan areas, Kumbum became the scene of an encounter between the Mongols and the local authorities. Consequently, parallel to developments at Sakya in Central Tibet, Repa Karpo was established as the main religious authority along with a Dru lord, a layman called Driwo Awu, who was tasked with overseeing secular matters (Khamtö Logyü II, 39-41, 50; Barom Namthar [Life Stories of the Barompas] 220, 235). The Mongols therefore introduced 
an administrative structure which guaranteed their control of Nangchen, and Kumbum monastery started to develop into a local power centre with authority to rule over twelve myriarchies (Barom Namthar, 234-236). To lend weight to this, Repa Karpo further extended the Kumbum complex with Nangso Chenmo - an impressive palace including a remarkable temple and a monastic compound. It was probably during this period, with the advent of Mongol administrative divisions, that Nangchen was organized into 25 pastoral clans and eighteen monastic districts (Khamtö Logyü II, 40, 79-87; Tsomu 2006, 37). These religious units, each governed by a main monastery, are all said to have originally been of the Barom Kagyü denomination, perhaps owing to early Barom supremacy in the region. Thereupon Nangchen grew to become a Kagyü stronghold and the Barom tradition, which was to undergo a substantial decline in later times, became the principal religious and political force in the kingdom in the initial stages of its existence. In fact, the rise, decline, and successive revivals of Barom Kagyü were inextricably bound to the secular history of Nangchen.

Consolidation of the religious and secular dominance of the Barom school in Nangchen as well as the centralization of power took place during the reign of Tsangsar Lümé Dorjé (1226-1292), Repa Karpo's principal heir. After Repa Karpo's demise, Chögyel Pakpa (1235-1280), whose success at the court of Kublai Khan and the resulting supremacy over Ütsang and other Tibetan areas are well documented, sanctioned Lümé Dorjé to exert both religious and temporal rule over upper-central Nangchen. This no doubt transpired in 1274 when Pakpa was passing through Nangchen (Khamtö Logyü II, 164). However, it must be emphasized that Lümé Dorjé originated from a local clan and rival to the Dru - the Tsangsar - and in the early phases of Nangchen's development, the Dru had yet to emerge as the lineage of Nangchen kings (Depter Mukpo [The Maroon Annals], 321-322).

The subsequent Barompa ruler in the Tsangsar lineage was Jangchup Zhönnu (1254-1323), Lümé Dorjé's nephew. It would seem that Jangchup Zhönnu's early reign marked the last period of political and religious unity in the realm. During this overlord's lifetime, preparations were being made to establish a Dru son as a rival ruler. It was a clan matter - the Tsangsar had been in power for two generations now, and the Dru had been waiting anxiously for the opportunity to seize power again and had been preparing to gradually settle Dru Chökyi Gyeltsen on the throne. Sources report that Dru Chökyi Gyeltsen was first proclaimed abbot of Kumbum by the Yuan emperor Temür Khagan (ruled 1294-1307) and that a little later, Sakya Khön issued a decree addressed at the monastic communities in Nangchen and in the Dru homeland of Trirapkha, which stated that the throne in Nangchen 
should be occupied by someone with the title of chögyel, dharmarāja, which refers to the pan-Tibetan and Indic idea of an ideal sovereign who rules in accordance with Buddhist teachings (Barom Namthar, 262-263). Alternatively, Khamtö Logyü (II, 165) recounts that in 1294, a high-ranking official in the Sakya-Yuan hierarchy and a disciple of the influential Sakya master Ga Anyen Dampa (1230-1303), who went by the name of Sangha, issued an edict and seal that exempted Chökyi Gyeltsen from paying taxes (Khamtö Logyü II, 165). It is possible that the strong ties between the Dru clan and the Sakya rulers dated back to the time when Chögyel Pakpa visited Kumbum. However, some sources claim that the 1294 edict had in fact been issued even earlier and that it also granted Dru Chökyi Gyeltsen the right to rule over both Nangchen and his native Trirapkha (Gedrong Logyü [Chronicle of the Good Drongpa Clan], 99; Barom Namthar, 262-263). Other authors attribute the edict to Chögyel Pakpa himself (Khamtö Logyü II, 166).

Nonetheless, all local chronicles are unanimous: Dru Chökyi Gyeltsen ascended the Nangchen throne as chögyel in 1300 . He received the right to collect tribute and corvée in the territory comprising Trirapkha and up to and excluding Kumbum. This local power centre was handed down to Jangchup Zhönnu and his transmission holders (Khamtö Logyü II, 165; Nangchen Gyelrap, 28). Given this state of affairs, Jangchup Zhönnu had no other choice but to build another castle to centralize the power he still exercised. Consequently, in 1302 the Tsangsar stronghold was built and Jangchup Zhönnu moved into the compound, which in 1323 was most probably where he died (Nangchen GönkhakJungwa [Origins of Nangchen's Monasteries], 332).

Chökyi Gyeltsen had influential relatives: his maternal uncle, Be Jangchub Gönpo, and cousin, Yonten Pal, were both high-ranking officials at the grand temple of Nangso Chenmo (Barom Namthar, 262; Khamtö Logyü I, 39). During Jangchup Zhönnu's lifetime the uncle had already intervened at the Sakya court in what I assume was a power struggle, and obtained an edict which proclaimed Yonten Pal, Chökyi Gyeltsen's maternal cousin, the rightful heir to Tsangsar castle. The Barom Namthar (262-263) implies that this occurred in 1324. As a result, the realm was separated into two domains of equal status according to the Sakya-Mongol legal system: one territory under Dru Chökyi Gyeltsen, the Nangchen gyelpo, and another under his maternal cousin who governed from Tsangsar (Khamtö Logyü II, 166; Nangchen GönkhakJungwa, 332). To further emphasize the split in power, all the Barompa relics, precious objects as well as ritual implements, were relocated from Kumbum to Tsangsar (Barom Namthar, 233, Khamtö Logyü II, 48-49). This division was accompanied by a further fragmentation 
of the Barom transmission of doctrines and rituals, which I have described elsewhere (Turek 2018).

Local sources recall in some detail these numerous factions, all bearing foreign edicts, and locate the power struggle in and among the three local centres of power: Kumbum, Nangso Chenmo, and Tsangsar. These monasticpolitical institutions would at times have one overall steward, such as Chökyi Gyeltsen at Nangso Chenmo, and at other times two persons in charge, one to oversee the monastic and another to supervise secular affairs. Abbots, monastic administrators, and lay officials were all strongly bound by kinship ties and religious allegiances. This created a complex, shifting landscape of clan loyalties, marriage alliances, and religious fidelities, which provided an opportunity for outside authorities to issue mandates that were expected to solve inner conflicts of power. All this led to the formation of Nangchen as a polity and the emergence of Dru Chökyi Gyeltsen as the first king. But how do our sources represent the very first ruler as chögyel? Dru Chökyi Gyeltsen is described as being accomplished and learned in both secular and religious matters; he is also presented as someone who was a figure of authority respected by both lay and monastic leaders (Khamtö Logyü II, 62-64, 165; Barom Namthar, 262-263). A ritual virtuoso and a well-read monk, who, like many luminaries at that time, had received his training at the Sakya capital in Central Tibet, Chökyi Gyeltsen became the transmission holder of the previous Barompa patriarch and ruler, Lümé Dorjé (Khamtö Logyü II, Barom Namthar, 262-263, Nangchen Gyelrap, 27).

The Dru, which was Chökyi Gyeltsen's paternal clan, had already set a precedent for local power. Chökyi Gyeltsen's father was the aforementioned $\mathrm{Awu}$, who had acted earlier on as the secular myriarch in the local government under the auspices of Goden Khan. Although there were several clans that competed for power at that critical time of Nangchen's formation, in contemporary historical accounts, only the Dru are portrayed as the glorious bloodline endowed with a divine origin (Nangchen Gyelrap, 20-22, Dge 'brong lo rgyus, 42). The same passages also describe the Dru as arriving in Nangchen from outside.

To some extent, this theme of the external origin of the ruler is reminiscent of Marshall Sahlin's $(1985,2008)$ interpretation of the 'stranger-king' concept that he originally developed about Indonesia and Oceania, and which could also be applied to describe the Central Tibetan Yarlung emperors. However, 'the potency of alterity' (Sahlins 2008, 192) would mean that kings were the real power holders, when in practice, as some of Sahlin's critics have observed, kings often enjoyed great prestige but little real authority (Oosten 1988, 269). Even though the Dru dynasty had been attributed an exalted rank, 
it was not the only contender for power. While their moral superiority and their claim to royal status were never challenged, over time their political authority waned.

During the Ming era in China (1368-1644) the king and local aristocratic estates remained independent of any foreign regimes, as Barom Namthar (256) mentions in passing. No further mention is made about the state of affairs in Nangchen during that period in any of the chronicles. The omission of facts has been linked to the empowerment of subalterns by overlooking inconvenient truths (Rowland 1993), but I strongly suspect that our sources did not find sufficient or adequate historical references, given a certain vagueness surrounding the same period in Central Tibet.

Local sources leap from the Mongol period to the year 1634 which saw the ultimate destruction of Kumbum when the Eastern Tibetan prince of Beri, eager to extend his scope of authority and to win territory for the Bön, invaded Nangchen (Nangchen Gyelrap, 38; Khamtö Logyü II, 3, 171). The aggressor was defeated by Quoxot forces in 1640, but the 'Barom root' and at the same time the royal seat and capital of the realm, was never rebuilt. The king managed to escape, but the utter destruction of Kumbum had a devastating effect on the development of the Barom school (Turek 2018).

The memory of Kumbum monastery is celebrated in all contemporary Nangchen chronicles as a basis for the organization of power which would eventually lead to the creation of a polity and territorial identity. In local writings, both the emergence of Kumbum and the rise of gyelpo, as the process of centralizing authority, are linked to Mongol supremacy over Tibet and vast areas of Asia in the thirteenth and fourteenth centuries. It is possible that it was necessary for an external force from outside Nangchen to sanction the rise of a new local regime at that particular moment in time. However, the use of the Sakya-Mongol mandate in the narratives could further capitalize on a certain aspect of pan-Tibetan historical identity. In the self-image practised by many traditionally trained scholars and authors, the thirteenth-fourteenth centuries are known as the era when Mongol emperors revered and exalted their Tibetan preceptors. Reference to the Sakya-Yuan diarchy in local narratives has the effect of sanctioning the Nangchen state formation in the wider, Tibetan collective memory. This mnemonic technique also validates the legitimacy of local kingship by borrowing from a larger Tibetan cultural narrative.

Let us now return to our local history. Prior to the destruction of Kumbum, the Nangchen king waged war on the Beri armies and appealed to both the Fifth Dalai Lama (1617-1682) and Gushri Khan (1582-1655) for support. Subsequently, like most of the Tibetan world, Nangchen was included in 
the greater Tibetan territories ruled from Lhasa by the Central Tibetan Ganden Phodrang government. In the early stages of his rule over Nangchen, Gushri Khan issued an edict confirming the validity of the kingdom's previous administrative division (Khamtö Logyü II, 171). In the 1640s, the Fifth Dalai Lama upheld the king's right to rule over monastic and lay estates in Nangchen (Nangchen Gyelrap, 39). Tribute to Lhasa was enforced and introduced by means of a census. Later in history, the conversion of monasteries into Gelukpa provided the opportunity for Ganden Phodrang to encroach on Nangchen when it had become independent from Central Tibet (Turek, forthcoming a).

In 1724 royal authority was channelled into a new semi-mobile residence, the 'Nangchen Encampment' (Khamtö Logyü II, 3). A year later the kingdom was placed under the administration of a Qing amban who governed from Xining (Tuttle 2015), although the king remained directly responsible for political affairs and some religious matters in his realm. Here lies a major theme which is subsequently found again and again in all the sources mentioned herein. During the reign of the Yongzheng emperor, the Yunnan governor, Hao Yuling, summoned several representatives of Khampa kingdoms to Chamdo. An envoy of the eighteenth Nangchen king, Dorjé Tséwang (r. 1680-1734), also attended. On this occasion, the Nangchen king received the hereditary title of chanhu (Ch. qianhu, chiliarch, commander of a thousand men); lower-ranking officials obtained the title of behu (Ch. baihu, commander of a hundred men) and bechang (Ch. baizong, commander of fifty men). These titles were originally military decimal units in the Jurchen Jin state (1115-1234) and had continually been used along with the tusi system by China's dynastic regimes since the Yuan era to exercise nominal or real power in borderland areas. Leaders of several Eastern Tibetan groups or polities, such as Choné, Hor, Golok and Repkong, had received the qianhu title during the Ming period (Tuttle 2015; Weiner 2012, 69). For the Manchu dynasty, the ranks of qianhu, baihu, and baizong became a way of integrating pastoral societies like Nangchen in the Qing empire - while among agricultural populations, such as Dergé, native authorities often received the rank of tusi. For the Nangchen king and his subjects, these new ranks merely endorsed the validity of the earlier local administration; an additional edict was issued to confirm the king's right to rule over his realm (Barom Namthar, 275). Although in theory the ranks implied the right to enforce levies on a specific number of families, the structure merely reflected an administrative hierarchy rather than provide precise information about taxation.

To give one example of how the new titles were a means of maintaining the status quo rather than reorganizing the kingdom, the Nangchen king's 
qianhu title meant that he had the right to tax 1000 families, while in fact he received tribute from 700 households. These obligations were divided according to the binary system of 'monastic taxes' (sertrel) and 'lay taxes' (kyatrel). All subjects, regardless of their rank or position (Khamtö Logyü II, 81, 86; Nangchen GönkhakJungwa, 410-411) were expected to pay these levies. However, there is some evidence to support the theory that by the nineteenth-twentieth centuries the king only taxed dependants who lived on his estates and that he lacked the leverage to make decisions concerning land use in his realm or even to negotiate during disputes over land. According to Yudru Tsomu (2006, 37), the Nangchen ruler had the right to allot land, but 'he did not enjoy the real power to administrate [these lands]'. Still, some monarchs are remembered for having issued edicts that relieved certain monasteries of fiscal duties. For instance, on one occasion, a royal prince was recognized as a reincarnation of an abbot; for this reason, the king granted his monastery tax exemptions (Nangchen GönkhakJungwa, 410-411).

In our sources, it is obvious that the Qing qianhu rank became a vital part of the local process of legitimating the monarch in the eyes of historiographers. No author forgets to mention the title, and it is frequently used throughout the texts much the same as the title chögyel. Further on in this chapter I will elaborate on how the concept of chögyel was implemented in Nangchen, but here I wish to briefly discuss how the rank of qianhu is used in contemporary negotiations of the local past. Nangchen qianhu-kings were deliberately forgotten when history was 'arrested' during the Maoist era, when only one version of the past was authorized; all Tibetan matters had to be subordinate to China, hence the Nangchen king was relegated to the role of qianhu, which reflected the position of his realm as a dependent periphery of the Qing Empire. Such a one-sided presentation is a gross distortion of the local perception of the title. For the authors of contemporary chronicles, the rank of qianhu attests to recognition of the gyelpo and to his elevation above all other members of the local elite through the official approval by a foreign and much more powerful sovereign, even if we assume that the title merely connoted a peripheral or obsolete function in the complex imperial hierarchies. That the king may also have enjoyed special royal esteem even among Han and Hui traders passing through Nangchen is reflected through anecdotal evidence provided by the German traveller Albert Tafel, who passed through Nangchen at the beginning of the twentieth century. His travelogue relates the many difficulties he faced while traversing Nangchen without the king's knowledge and permission. He also reports (Tafel 1914, 145) that Han merchants used the term wang (king) - a Chinese equivalent of the Tibetan title gyelpo - to refer to the Nangchen ruler. 
In other words, it is significant that local authors commemorate and celebrate in their writings the fact that the king was granted the rank of qianhu by China's Manchu dynasty. Similarly, Nangchen historians highlight the role the Sakya-Mongol edict played in the enthronement of the first gyelpo and in the confirmation of his rights by the Fifth Dalai Lama's regime in recollection of the foreign endorsement of the Nangchen kings. Ironically, since these very components also consigned the kingdom to larger political structures which, thanks to their historiography and cartography, appropriated the gyelpo's territories with great skill and eloquence, they also became the primary reasons for Nangchen's provincialization in the sense of its position on the periphery of Lhasa-centric and Sino-centric narratives. Today these memories of the foreign mandate play an important part in politics of representation designed to negotiate the past as a testimony to local power.

It is also important to understand that the local meaning of the Qing titles and insignia bestowed on the Nangchen elite typifies the encounters between inside and outside in the 'matrix' of the Sino-Tibetan borderlands, as Gros describes in his introductory chapter to this volume. The local reception of the qianhu rank, whether seen as hybridity or acculturation, constituted an internalization of an 'external' sign of inclusion. It was one of the many phenomena that made Nangchen and Kham an ambiguous, inconsistent space. Regardless of contemporary recollections of the king's position in the local hierarchy, Nangchen rulers may have been granted legitimacy to be kings, but their rights to actually govern were either never universally recognized or short-lived. Nineteenth-century travellers inform us that the king had limited influence over secular and monastic districts: the power of the king was only effective in the immediate vicinity of the capital (Grenard 1904, 366), meaning the four districts around the capital represented by four baihu.

By the nineteenth century the gyelpo presided over 33 'inner' administrative districts, while the 25 headmen of 'outer' districts of Gapa were, it seems, self-governed from Jyekundo. The king's four ministers (baihu selected from a larger number of officials referred to by the same title) presided over the fiscal-administrative units that were characterized by varying levels of independence from the ruler. A Chinese survey carried out during the hegemony of Ma Bufang in Qinghai, and therefore also in the Jyekundo area, as quoted by Sperling $(2003,13-35)$, speaks of 175 local headmen who were linked to the king in different ways. Nangchen lacked both a political force that would dominate this intricate network and a coherent economic superstructure that could accommodate all local influences. For this reason, 
I concur with Gruschke (2004, 105-108) and Yudru Tsomu $(2006,37)$ when they say that Nangchen was more of a federation of clans united under the royal banner than a centralized polity, and that loyalty to the king was borne out of a sentiment for him as 'a moral and social institution' (Gruschke 2004, 108) rather than because he was recognized as a de facto leader.

A closer look at the socio-political structure of Nangchen reveals that its ideology of political power was borrowed from Indic mythology as was the case of many historical Hindu and Buddhist states of Southeast Asia. Stanley J. Tambiah explains that they were organized according to cosmological principles and based on the assumed correspondence between the superhuman macrocosm and the human microcosm:

The kingdom was a miniature representation of the cosmos, with the palace at the center being iconic of Mount Meru, the pillar of the universe, and the king, his princes, and ruling chiefs representing the hierarchy in Tavatimsa heaven [...]. (Tambiah 1976, 109).

Nangchen Gar, which served as the capital from the early eighteenth century onwards, was topographically structured after the cosmological construct of the mandala, with the king at its centre as both the ideal Buddhist ruler, cakravartin, and simultaneously cosmocrator, the ruler of the world. The mandala model of four cardinal points placed around a focal point was mapped onto the ground plan of the capital and at the same time onto the structure of political functionaries and ministers. As mentioned above, the king had four ministers, whose land surrounded Nangchen Gar. Moreover, it is no coincidence that the 33 officials and their districts, who were directly subordinate to the chögyel, correspond to the 33-unit configuration typical of Hindu and Buddhist cosmologies and religious-political compositions, which in the different variations on the model reflected the hierarchy in the divine realm of Trāyastrimśa (lit. 'thirty-three'): Indra, the four guardians of cardinal directions (lokapāla), and 28 subordinate gods. ${ }^{1}$ This Indic blueprint proved successful in distant Buddhist kingdoms, such as Java, Thailand or Burma, partly because it elevated the monarch to the holder of the sacred

1 It is interesting to note that, as shown by Yudru Tsomu, the kingdom of Dergé had a similar structure (Tsomu, in this volume). There is no doubt that aside from the regular political alliances, there were many continuities in the organization of the two kingdoms and their topographies. If my assumption that the broader Asian cosmological paradigm found its way to Kham is correct, the question remains how that came about and if the regional source of its reproduction was Dergé, which had the reputation of the cultural center of Kham. 
teachings of the Buddha, a cosmocrator, and an intermediary between the realms of the divine and of humans (Tambiah 1976, 108-109).

The Indic cosmological model for organizing society and for the topographic layout of the capital illustrates the idea of 'galactic polity', a galaxy-like constellation of entities that are autonomous yet centred (around the figure of the king) and fixed in their trajectory (predetermined social order) (Tambiah 1976, 113). This concept has already been applied to describe Khampa principalities (Samuel 1995, 61-63) and, though the application of Tambiah's model onto Kham has met with some criticism (Holmes-Tagchungdarpa 2010, 10-11; Tsomu 2006, 28), the critiques are based on historical examples of Lhatok and Nyarong, two Eastern Tibetan polities that were not organized around the principle of kingship. The case of Nangchen, as presented in modern chronicles, was unquestionably different and therefore offers a vivid example of Tambiah's concept. Although the cosmocratic influence of its monarchs was greater than their political control, their exalted status and symbolic capital 'extended beyond their ability to enforce it - thereby creating a far-reaching cultural subordination among hinterland peoples without the benefit of real-political coercion' (Sahlins and Graeber 2017, 335).

The mnemonic practice of describing the political organization in Nangchen in ways which correspond to the concept of a galactic polity can also convey contemporary agendas, such as legitimizing the kingdom as a power centre in its own right, and assist in the reconstruction of local identity. Although decentralized in terms of their jurisdiction, the Indic cosmological components employed in Nangchen's socio-political structure emphasized the focus on the king as the centre of the mandala. Therefore, although the official state discourse locates the former kingdom in a peripheral, 'borderland' position, recollection of the moral and symbolic centrality of kingship lays emphasis on autonomy and self-referentiality, and shifts local awareness from the margins to its own centre. Given that cosmologies are narratives that focus on a sense of belonging, remembering the local past in terms of subjecthood to the Nangchen king could become an effective way of reconstructing local identity.

It was common for many Tibetan and Asian societies on the whole to identify kingship with the rule of law, which was associated with the Buddhist doctrine in particular. In a recent piece of work, Charles Ramble $(2008,313-314,325-326)$ states that this principle, according to which the monarch had to be associated with religion, was typically applied across Tibetan societies. A monarch protected his subjects with the authority of Buddha's teachings which portrayed him as a true chögyel. It was, among 
other elements, this image of pious fairness that elevated him above other lower-ranking leaders.

Throughout local histories, the Nangchen king is presented as the one who protected his realm and defended the faith; mention is often made of the idea that he ruled according to the law. Even if we have no evidence about the right of the gyelpo to exercise his rule over (or as it is phrased in our chronicles, 'to protect') a specific territory, territorial awareness did develop in Nangchen, as attested to by our sources (Turek, forthcoming a). The idea of a king as the protector of his realm is manifest in Nangchen Gyelrap (80) which reproduces a map based on a land record made by one of the gyelpo.

The map locates Nangchen inside Kham and next to Central Tibet and Amdo. Although geographically imprecise, it represents the major points inside the kingdom such as the royal capital, the trading town of Jyekundo and the four main rivers running through the kingdom (Drichu, Dzachu, Machu, and Chichu). The smaller, striped map at the bottom with the word 'Tibet' written in Latin alphabet represents the location and perceived size of Nangchen in relation to Central Tibet and the Himalayan kingdoms of Nepal, Sikkim, and Bhutan.

A Buddhist king who rules according to Buddha's sacred teachings will typically also be known for protecting animals from hunters. Consequently, local histories relate how the Nangchen ruler passed laws to preserve wildlife (Barom Namthar, 280; Nangchen Gyelrap, 22, 75). Today, recalling the strictness of the king's law might be a way of attesting to the fact that, as a chögyel, the king met his people's expectations by protecting his realm and defending the moral principles codified by Buddhism:

The king's law [concerning] secular (srid phyogs) matters was very strict. If a man was slain, the perpetrator had to have his one eyeball gouged out, his one ear shorn off and one foot chopped off. If a yak was stolen, [the thief] paid nine measures [of barley, which] in reality amounted to ten. If a wild animal was slain on the holy Nyenpo mountain, the hunter's right index finger was cut off (Nangchen Gyelrap, 74-75; Gedrong Logyü, 92).

Another way in which religious themes are used to sustain or to add to the idea of Dru patriarchs being elevated beings worthy of royal status was based on the long-standing reputation of Nangchen as a 'nest of the cotton-clad yogins, region of meditators' (retsang gomdé). Throughout the history of contemplative lineages (drupgyü), Nangchen was famous not only for its number of convents, hermitages, and monastics but perhaps most 
Figure 13.2 Sketch map of Nangchen based on a narrative land record composed by one of the gyelpo

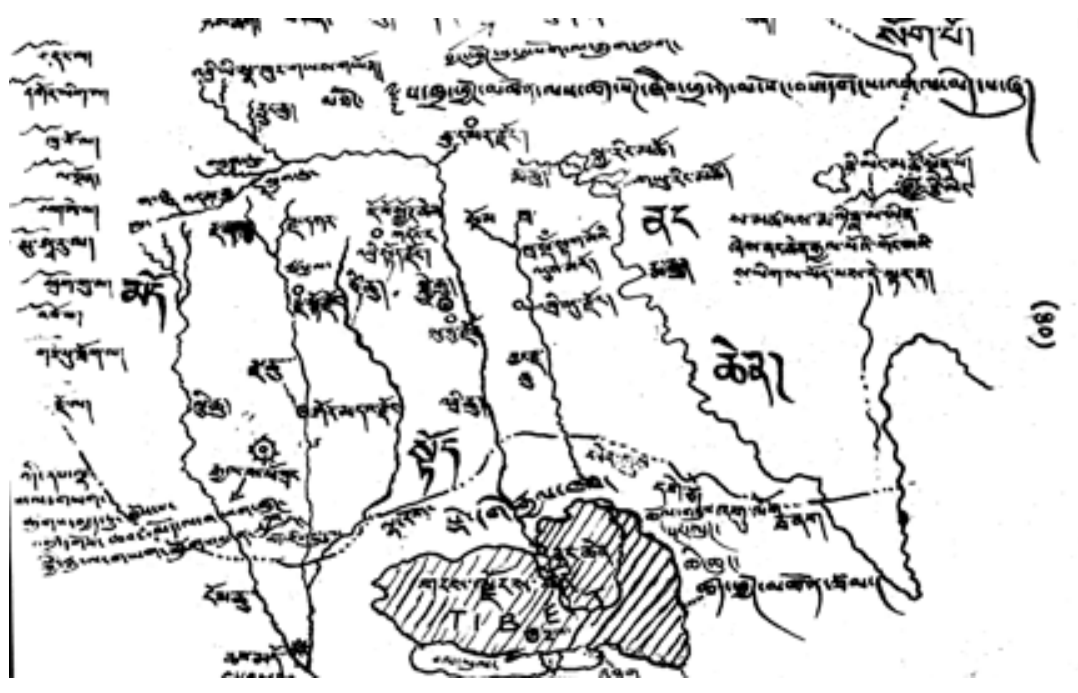

Source: Nangchen Gyelrap, 80

of all for the many exceptional masters of meditation who originated from or had been educated in the pastoral kingdom. In oral lore and in modern chronicles we still come across songs extolling Nangchen as the perfect environment for Tantric practices which even extended to the laity: 'all men were meditators, all women were meditators' (Khamtö Logyü II, 2-3). In keeping with the contemplative reputation of their realm, it is said that several notable members of the Dru dynasty became deeply involved not only in the royal business of founding and maintaining religious centres, but also in the pursuit of a personal, spiritual vocation. During the first few generations, Nangchen kings are remembered as ordained monastics. Later the dynasty became secularized and passed down royal authority from father to eldest son; they also lost their exclusive interest in the Barom school and embraced the doctrines and rituals of various schools and lineages.

Returning to the self-ascription of 'Nangchen the region of meditators' (nangchen gomdé) briefly introduced above, the second part of the abbreviation-compound gomdé is worth some elaboration in the context of Kham as a heterotopic space in which multiple, contradictory or even mutually exclusive places coexist and compete throughout time (see Gros, this volume). The meaning of dé ('region, district, section, faction, group, department') relates to a regional entity which is both a social collective and a part of a larger body. The communal aspect of the designation dé 
may relate to the egalitarian style of Nangchen lamas, who, according to legend, famously imparted the most advanced teachings on meditation and mystic experience to anyone and everyone. But how can we understand the connotation of dé as a 'region' (or in terms of any other equivalent of the word dé which relates to a part of a larger whole) in reference to the Buddhist 'kingdom of Nangchen' (nangchen gyelkhap)? For anyone eager to categorize Nangchen as either an autonomous or a tributary realm, this emic inconsistency irritatingly complexifies the local claims to territory and the reverence towards their native tradition of kingship. In a study of regionalism quoted in the current volume, Vicente Rafael problematizes the 'region' as a place of otherness that destabilizes and complicates the claims of powerful centres (Rafael 1999). Kingship and local identity in Nangchen were not formulated as political claims challenging larger powers dominating the region from the outside. Judging by the behaviour of several kings and other members of the local elite, they were rather pragmatist and opportunistic when it came to dealing with Quoxot warlords, the Qing, Ma Bufang, or the Ganden Phodrang. In an event of an interference or an invasion, the Nangchen ruling elite frequently bet on the winning horse, similarly to the Dergé strongman Jagö Topden. So, perhaps - precisely because they saw the precariousness of their own geopolitical position - by reiterating their self-chosen epithet 'region of meditators', the people of Nangchen realistically acknowledged that they were merely a 'region'? However, they were no ordinary region, but one that united Tantric meditators. Thus, the proliferation of the legend of Nangchen gomdé could generate a utopian response to the dystopian visions of war or exploitative overtaxation. By proposing this interpretation, I am by no means claiming that Nangchen was a 'kingdom' for the insiders and a 'region' for the outsiders. As discussed throughout this volume, in Kham, the notions of inside and outside were notoriously interwoven and convoluted in space and time. A good example of this is the Nangchen gyelpo's title of qianhu, an object of great local pride, but which placed the king among several other rank holders positioned on the margins of the Qing territories. ${ }^{2}$ However, the local esteem of the qianhu title was so great that it survived the empire well into the 1940 .

Even if the locally/regionally relevant discourses of power in Nangchen often took the form of a religious orientation of kingship and society, the

2 Compare also the case of Ming dynasty titles bestowed on members of the Central Tibetan elite in the period between fourteenth-fifteenth centuries. Although they were not titles of political recognition, they were used for competition among Tibetans themselves; see Schwieger (2009-2010). 
complexity of these discourses did not exclude regional politics. Thus, the presentation of Nangchen as a Buddhist society develops a horizontal and a vertical significance as the notion of the 'region' discussed by Vicente Rafael (1999). The image of Nangchen as an especially pious region seen from a lateral perspective could have been a way to highlight their special status among other Eastern Tibetan polities ('regions') subordinate to the same power. Thinking vertically, the 'regional' positioning of Buddhist kingship and society could have been a local strategy of injecting meaning into relations with a higher political power flowing from 'outside'. The 'region of meditators' is thus rendered as a site and source of ritual power for the distant emperors or foreign rulers. Multiple historical precedencies for this type of thinking can be found in the histories from Central Tibet, in which the politics of the Mongol/ Manchu-Tibetan relations were sometimes imagined through the lens of the 'priest-and-benefactor' (chöyön) concept. According to this idea, various Tibetan hierarchs such as the Dalai Lamas embodied the ritual authority of the Tantric guru and of religion, more broadly, as towering over the worldly and as such, transient, rule of the khan or emperor they had links with. If the relations meant in practice that the Tibetan ecclesiastic was a local representative of the Qing and that Central Tibet was an extension of the Qing empire, changing the discourse from that of political subordination to ritual and religious supremacy meant asserting ownership of the discourse. I would like to propose the same type of Buddhist imagination working for the image of Nangchen as 'region of meditators'. As one local chronicler describes Kyodrak, one of the most powerful monasteries in the realm, founded in fourteenth century with a donation of the last Yüan emperor:

Kyodrak monastery became the crown ornament among the sublime objects of veneration for the Hor, Lijang, Minyak kingdoms, and so on, as well as for the Chinese, Tibetans and Mongolians. (Kyodrak Shedra: 28 )

The moral authority of the Nangchen king was linked to his commitment to support religious institutions in his realm. This translated into the physical realm when Tsechu monastery was erected next to the royal palace, calling to mind the tradition of the local religious-secular power centres of Kumbum, Nangso Chenmo, or Tsangsar (Nangchen GönkhakJungwa, 486-494). Perhaps the king also wished to style his capital on Dergé, where the royal palace was situated next to Gönchen monastery. Neighbouring Dergé was seen as the cultural heart of Kham, with which Nangchen enjoyed close yet constantly shifting relations, expressed through marriage alliances, wars, and unions. 
Today, both Tsechu and Gönchen monasteries have been rebuilt, while their secular counterparts, the royal palaces of Dergé and Nangchen, lie in ruins that have either been intentionally concealed or rebuilt in form of a tiny temple. In the ethnic Tibetan areas of contemporary China, monuments to secular power can be reassembled through mnemonic practices such as narrative accounts that focus on 'place memory', and although Nangchen palace is mentioned in all local sources, only the one published in exile gives a description of it (Depter Mukpo, 125-128).

Elsewhere I mention (Turek, forthcoming a) how the chronicles describe a specific category of rituals dedicated to the Nangchen ruler's longevity and which was called kurim; this was an obligation that certain monasteries, hermitages and lamas had to fulfil. The mutual benefit resulting from the ritual was meant to legitimize and in a way sanctify the king, while bestowing privileges on the institutions involved. Accordingly, kurim monasteries received the status of quasi-independent territories governing whole districts, including a large number of dependants. There may have been various reasons for elevating these particular monasteries, but the choice of different monastic schools once again styled Nangchen after Dergé where royal patronage over monasteries of various denominations had been the preferred line of action since at least the nineteenth century.

One particularly ceremonial type of kurim devoted to the long life of the Nangchen monarch is described as follows:

Annually, during the kurim ceremony, the precious Kangyur was completely read aloud for the king and a retinue of his subjects, who would travel to where the ritual was held. The monasteries were obliged to take turns [to carry out the ritual], and when theirs arrived, [the ceremony was performed by] around fifteen lamas and monks. There was a custom: on the way, while travelling, the lamas responsible for kurim would lead the king's mules, laden with his belongings, [while] it was required that the lamas' caravan would be led by the chant master [of Tsechu monastery?] (Khamtö Logyü II, 85).

As longevity rituals are evoked in contemporary local history writing, their mnemonic potential can be harnessed as we follow the trail left by the pan-Tibetan heritage of the Yarlung Empire. In ancient Tibet, kurim rituals were carried out to protect the emperor's divine body which served as a metaphor for his realm (Walter 2009, 166-174). As the ritual later spread throughout the Plateau, it was also performed in villages for the collective good of the community (Childs 2005). In Nangchen 
the ceremony depicted the local political cosmology in which the body of the sovereign represented the land and the territorial identity of his subjects. That is why remembering this category of rituals today may be a way of contributing to local identity reconstruction. If we also agree with Samten Karmay $(1998,245)$ and Margaret Prins $(2007,194)$ that Tibetan rituals are reenactments of mythical narratives, then, by recalling rituals associated with kingship, the entire local tapestry of symbolic meanings and practices is recreated, which can be used for the reconstitution of place memory.

The social nature of kurim brings us to the major aspect of these kingshiprelated rituals. Rituals in general and kingship-related rituals have a strong performative element which is often communicated to the audience through insignia of power. Contemporary local sources emphasize the special headgear worn by the monarch; a top hat decorated with red coral presented by a Xining amban. This was a sign of a qianhu, and lower-ranking members of the Nangchen ruling elite who enjoyed the rank of baihu also received buttons made of semi-precious stones, though coral was reserved for the qianhu. Together with the qianhu title, the hat was bestowed on native leaders on the periphery of the Qing Empire as a sign of their assimilation into the administration, but in the Nangchen narratives, the insignia marks the prestige of the one and only legitimate ruler.

According to our genealogies of kings, the monarch was at the centre of several rituals whose effectiveness relied on their power-oriented symbolism and theatricality. In addition to kurim - one example of a religious ceremony in the service of the king - secular rites and festivals took place in the royal palace grounds. Annual horse races and the protocol governing welcoming ceremonies for the monarch are particularly good examples of how vividly local chronicles recollect the performances of local identity and its political cosmology:

When the king returned home on horseback, four grey silk banners had to be raised before him one by one. [There were officials] equipped with staffs, monastic robes and clay drums. Furthermore, twenty-five bechang, [representatives of] kurim monasteries, some fifteen monks of the Tsechu convent presided by the four chamberlains and the behu all gathered at this place, [as well as] lay people and monks. Peacock canopies were raised for both Adé Rinpoche and for the king. On their both sides walked four lay people, bearing leopard-skin banners and two monks bearing canes. Behind, members of the court had to line up along with [them]. (Nangchen Gyelrap, 74-75, Gedrong Logyü, 92) 
Performances such as the one described above, which include symbolic implements of authority, have the capacity to linger in visual memory as de facto mnemonic devices that are effective in the restoration of what kingship looks and feels like and which can be used in the wider context of identity reconstruction.

To get back to the subject of the performativity of rituals dedicated to the king's long life, as described above, a kurim ceremony included the recitation of the Kangyur, the canonical collection of scriptures believed to be the words of Buddha. Performed by alternating monasteries, the ritual emphasized the interdependence of prestige, moral obligation, and merit which is important for Tibetan societies and many Buddhist states across Asia. There were uniquely Tantric types of kurim in Nangchen and several reincarnated lamas or yogins, who were believed to be particularly powerful yogins, were paid from the king's treasury to perform longevity practices for the king in ritual seclusion (Tulku Urgyen 2005, 171, 177). The fact that not only merit but also Tantric power was collected and utilized to sustain the monarch was a special feature of kingship in keeping with Nangchen's reputation as 'the realm of meditators'.

The king is said to have been personally highly involved in religious life. Oral tradition has recorded how some monarchs dwelt in meditative seclusion and, in order to fully embrace the life of a renunciate, passed on their function of chögyel to their eldest son. In other narrated scenes, subjects plead with the king, who is practising Tantric meditation in ritual seclusion, to resume his royal obligations for the sake of all the people in his realm. The king returns reluctantly - yet another element adding to the specifically Tibetan image of an ideal monarch (Ramble 2008, 325-326).

A story that is still recounted again and again today in Yushu T.A.P. tells how the last king, Trashi Tséwang Dorjé, died while meditating in retreat in the vicinity of the Gyanak Mani pilgrimage site outside Jyekundo (another version of the same event, which comes from Nangchenmi in exile, stresses that the king's isolation was not of a voluntary nature and that he had been sentenced to home arrest). Of course, remembering that the king's virtues were in keeping with Buddhist teachings is important for reviving the specific Tibetan identity of his former realm and for reconstructing the interdependent identities of former subjects. In addition to this, I would like to highlight how the Nangchen kingship narrative, especially elements concerning the legitimacy of Dru kings, is enhanced by an association of kingship with Tantric meditation in seclusion and the ritual power believed to be collected through these practices. Emphasis on Tantric mastery as part of the Nangchenmi's mnemonic process serves to reconstruct the traditional mythical-religious make-up in the realm in the current process of identity revival. 
The Nangchen kings enhanced the charisma of kingship with the charisma of meditation and mysticism. However, in twentieth century Kham the charisma of royalty itself was apparently important to the reputation of leadership, as we learn from Yudru Tsomu's chapter in this volume. The Derge strongman Jagö Topden, while challenging the traditional model of hereditary kingship, also appropriated some of its charisma through adopting the title of the 'hundred-year-king' (gyalo gyelpo). It is interesting to note that the leader of the opposing faction which represented the traditional model of leadership and was intent on defending it, was the Nangchen king Trashi Tséwang Dorjé's own sister.

\section{The Demise of the Kingdom: Legitimacy and Conquest}

From the beginning of the twentieth century onwards, Kham became an area of increasing tension and unrest. In 1911, during the reign of king Wangdrak Tsering Lhagyel, Nangchen fell under the authority of the Hui Ma clan which ruled from Xining. This barely changed the actual status quo on the ground, with the king presiding over baihu and baizong as well as over the semi-independent monastic estates; this might be one of the reasons why the legacy of the most famous Ma warlord, Ma Bufang (1903-1975), was largely 'forgotten' in the Nangchen chronicles. Accounts of Ma Bufang's much-feared punitive campaigns against monasteries or families with overdue fiscal payments are mostly oral.

During the reign of the last monarch, a new power emerged in China communist forces defeated Ma Bufang and Xining fell in September 1949 (Marshall and Cooke 1997, 1593). The early presence of Chinese communists is mentioned in our sources but, as we shall see, depending on whether the material was printed in the P.R.C. or in exile, it is represented in different ways.

In June $195^{\circ}$ Chinese troops spread further south and took over Jyekundo, where they established their temporary headquarters as a necessary base for the subsequent invasion of Central Tibet (Nangchen Gyelrap, 49). From Melvyn Goldstein's interviews with Tibetan informants we learn that Lhasa failed to conspire with both the Dergé queen and the Nangchen king to join forces to drive away P.L.A. troops. After 5 October, Nangchen became the corridor through which the $154^{\text {th }}$ Regiment of the People's Liberation Army transited to Riwoche and further on to the strategically important town of Chamdo (Goldstein 1991, 681-682). After the fall of Chamdo, the P.L.A. were able to proceed to Lhasa which they conquered without much resistance. 
In another paper I pointed out how certain contemporary Tibetan authors use myths in representing facts from recent Sino-Tibetan history to portray Chinese communist democratic reforms and their aftermath as an ideological and cosmological conflict rather than a political or ethnic one (Turek, forthcoming b). Nangchen Gyelrap accordingly credits the last king with a clairvoyant vision of the communist takeover, portraying him as a sage endowed with exceptional powers that emerge with the performance of prolonged and ritually efficacious Tantric meditation in seclusion. At the same time, the passage from Nangchen Gyelrap presents the author's interpretation of local history between 1950-1959:

What concerns oppression by the communist Chinese, the venerable king had a prophetic vision of the future and described them as enemies of the teaching and samaya-violators; [he saw how] three faces of the communist Chinese, drunk with three kinds of poison, would manifest three expressions:

First, there would be a time for [showing] a face of ignorance [wearing] a fake smile: they would call everyone 'brothers and sisters', paid one silver piece for a mere cup of cold water, would not collect the customary taxes and corveé labour. They would be very peaceful and gentle.

In the meantime, there would be a time for [showing] a red face of greed, beaming with delight: the Chinese would buy land at strategic points piece by piece and for surprisingly [high] prices, where they built roads and military barracks. They would be very cunning: under the disguise of opera shows, performances and pretending to have a friendly attitude, they performed medical experiments on humans and livestock, examined the amount of rainfall on wet fields. Suspicions clearly emerged [in the vision]. Because they enticed individuals to conflict, endless family fights broke out. They said that the oppression of the people was [now] eradicated and that weapon-making blacksmiths were no longer needed. The families who had swords were summoned and the weapons taken away.

Finally, there would be a time for [showing] a black face of anger, frowning terribly: land, possessions and cattle were collectivized. Several local lay people and members of the clergy were [invited for] inspection visits [to factories, etc.], [ideology] classes, and meetings. [But in reality,] district [authorities] tortured them [and they] died horrible deaths; the government eliminated them. On the other hand, people were [also] killed through heavy military action. In short, these techniques of deception, trickery and cunning [which took place] between 1950-1959 became clearly apparent [in the king's vision]. [...] (Nangchen Gyelrap, 51-53) 
The three phases of local history that are referred to in this fragment are in fact a fairly adequate representation of what transpired in the 1950 s as we know it from Western scholarship on Central Tibet and parts of Amdo and Kham. The period in question has been the object of intense negotiations between publications sanctioned by the Chinese state and works published in exile. The above extract is taken from a source published in India, whereas for instance Khamtö Logyü (II, 211), produced in China, mentions the Nangchen king's cooperation and his plans to re-establish the realm as part of new communist China. This contrasts with testimonies of Tibetan authors based in exile, who recount the armed struggles and atrocities committed in this first phase of the P.R.C.'s expansion into Nangchen. Thus, in 1950, according to Nangchen Gyelrap, after failed diplomatic attempts on the part of the king's father, Wangdrak Tsering Lhagyel, struggles are reported to have broken out throughout the realm. Many desperate people were driven to commit suicide, the queen was captured, and the king forced to comply with the new government (Nangchen Gyelrap, 52-53).

The year 1951 saw the establishment of the '[Local] Government of the Tibetan People's Autonomous District of Yushu or Upper Kham' (Tib. Khams stod dam yu shul bod rigs sa khongs rang skyong mi dmangs srid gzhung, Ch. Qinghai sheng Yushu Zangzu Zizhi qu renmin zhengfu) with king Trashi Tsewang Dorjé as its nominal head (Khamtö Logyü II, 211). In the newly created Yushu Prefecture, the years 1950-1958 saw further preparations for socialist reforms envisioned by Mao. Along with lower-ranking Tibetan cadres, the Nangchen elite had to undergo compulsory training, which, as the central government in Beijing hoped, would reform their thinking. We do not learn this only from the excerpt above but also from photographs reproduced in Nangchen Gyelrap (81-82) and dated 1950, showing king Trashi Tsewang Dorjé with his ministers on 'an invited sightseeing tour' through the factories and monuments of China (see also Dáša Mortensen, this volume). The Year of the Earth Dog (1958) marked the final demise of what constituted the kingdom of Nangchen: the royal authority of the Dru dynasty that had been ruling since the beginning of the fourteenth century and the prestige of the eighteen monastic districts, which contained the realm's rich religious culture. In all the recent histories of Nangchen, 1958 is remembered as a major traumatic milestone that brought about an irreversible change of society.

Since then, modern maps of the People's Republic of China delineate a small fraction of the former Nangchen kingdom, which they call Nangqian County (Ch. Nangqian xian) within Yushu Tibetan Autonomous Prefecture. The former centre of the galactic polity, Nangchen Gar, lies far off the beaten 
track and consists of the reconstructed Tsechu monastery and a minute temple where the royal palace once stood. Today, the centre of Yushu Prefecture is Jyekundo, which was elevated to this position following the devastating earthquake in 2010 . The need for a total reconstruction of the town after this disaster has provided the government with the opportunity of creating a new Shangri-La, a colonialist, urban fantasy about Khampa culture and history.

\section{Conclusion}

This contribution presents an overview of the revival of traditional history writing about the Eastern Tibetan kingdom of Nangchen, with special focus on the kingship narrative to which these new Tibetan-language histories give prominence. My understanding of the construction of the Nangchen kingship narrative is that the mnemonic process initiated to recollect the royal genealogy, legitimacy of rule and the socio-political organization in the kingdom draws on broader pan-Tibetan and Asian kingship narratives and cosmologies. These conceptions of kingship offer a tradition-sanctioned explanation of the structure, nature, meaning, and interdependence of the universe, society, history, place, state, and ruler. Indeed, the sudden suppression of the kingship narrative in Yushu T.A.P. in the 1950s destroyed the local sense of belonging, and the perception of tradition and of Nangchen Gar as a place where the authority of that tradition should be centred. Crediting kings once again with a divine status through historiographic practice has, at least in literature, the capacity to reverse or to stop the irreversible shifts that took place in Nangchen society.

Firstly, as Amy Holmes-Tagchungdarpa (2010) noted regarding Lhatok, royal genealogies have the potential to transfer local self-perception from a periphery of an external power centre to its own autonomous centre, and to represent this practice as a historical, and therefore authoritative process of renegotiation of the local past.

Secondly, I argue that remembering the Nangchen gyelpo in a close conversation with widespread Tibetan and Asian ideas of kingship - as the centre of a universe filled with complex meanings and tropes - contributes to the reconstruction of local identity. This mnemonic practice can restore the identity of the Nangchenmi as subjects to their legitimate king. Through its cosmological aspect, the literary return of good kings also shows the potential to re-establish the broken connection with local tradition and to re-emphasize the value of the landscape as its container. 
Kingship can also potentially serve as an axis for an imagined pan-Tibetan community. That the kingship narrative is in great demand on both sides of the China-India border can be illustrated by an anecdote I heard in Jyekundo in the spring of 2015 - about a man who went to various Tibetan communities in India, introducing himself as 'the king of Nangchen' not without some success, even though he had no credentials to prove his claim.

\section{Glossary of Tibetan and Chinese Terms}

Adé Rinpoche

Barom Kagyüpa

Be Jangchub Gönpo

bechang

behu

Bön

Chamdo

Chichu

Choné

chögyel

Chögyel Pakpa

Chökyi Gyeltsen

chöyön

dé

Denma Jamyang Tsultrim

Dergé

Dorjé Tsewang

Drichu

Driwo Alu

Dru

drupgyü

Dzachu

Ga

Ga Anyen Dampa

Gesar

Golok

gyalo gyelpo

Gyelrong

Gyanak Maṇi

gyelkhap
A lde'u rin po che

'Ba' rom bka' brgyud pa

'Be byang chub mgon po

be chang, (Ch.) baizong 百总

be hu, (Ch.) baihu 百户

Bon

Chab mdo

Lci chu

Co ne

chos rgyal

Chos rgyal 'phags pa

Chos kyi rgyal mtshan

chosyon

sde

Ldan ma 'jam dbyangs tshul "khrims

Sde dge

Rdo rje tshe dbang

'Bri chu

Tre bo a'u

'Bru

sgrub brgyud

Rdza chu

Sga

Sga a nyan dam pa

Ge sar

Mgo log

rgyal lo rgyal po

Rgyal rong (Ch.) Jiarong 嘉线

Rgya nag maNi

rgyal khab 
gyelpo

Gönchen

Hor

Jagö Topden

Jangchup Zhönnu

Jyekundo

Kangyur

Khampa

Kumbum

kurim

kyatrel

Kyodrak

Kyehu Khorlo Zangpo

Lhatok

Lümé Dorjé

Machu

Maṇi kabum

Minyak

Nangchen

Nangchenmi

nanglun

Nangso Chenmo

Nyenpo

qianhu

Repkong

retsang gomdé

Riwoche

Repa Karpo

Sakya Khön

sertrel

Songtsen Gampo

Tenpa Tsering

Tishi Repa Sherap Senggé

Trashi Tsewang (Topgyel) Dorjé

Trirapkha

Trokyap

Tsangsar

Tsechu

Ütsang

Wangdrak Tsering Lhagyel rgyal po

Dgon chen

Hor

Bya rgod stobs ldan

Byang chub gzhon nu

Skye dgu mdo

Bka' 'gyur

Khams pa

Sku 'bum

sku rim

skya khral

Skyo brag

Kye hu 'khor lo bzang po

Lha tog

Lus med rdo rje

Rma chu

Mani bka' 'bum

Mi nyag

Nang chen

Nang chen mi

nang blon

Nang so chen mo

Gnyen po

(Tib.) chan hu, (Ch.) 千户

Reb khong

ras tshang sgom sde

Ri bo che

Ras pa dkar po

Sa skya khon

gser khral

Srong btsan sgam po

Bstan pa tshe ring

Ti shri ras pa shes rab seng ge

Bkra shis tshe dbang rdo rje

Tre rab kha

Khro skyabs

Tshangs gsar

Tshe chu

Dbus tsang

Dbang drag tshe ring lha rgyal 
Yarlung

Yonten Pal

Yudröng
Yar klung

Yon tan dpal

Yu sgron

\section{Appendix: List of rulers mentioned}

Dru Driwo Awu (dates unknown) ruling with Répa Karpo (1198-1262)

Tsangsar Lümé Dorjé (1226-1292)

Tsangsar Jangchup Zhönnu (1254-1323)

Dru Chökyi Gyeltsen (r. 1300) - first in the line of kings

Dorjé Tsewang (r. 1680-1734)

Wangdrak Tsering Lhagyel (dates unknown)

Trashi Tsewang Dorjé (1910-1961)

\section{References}

\section{Tibetan sources}

\section{Barom Namthar}

Tshangs gsar blo gros rin chen. 2005. dPal ldan 'ba' rom bka' brgyud kyi rnam thar chos 'byung mdor bsdus gsal byed sgron me (Brief Religious History and Life Stories of the Glorious Barom Kagyüpas; an Illuminating Lamp). Zi ling: Mtsho sngon mi rigs dpe skrun khang.

\section{Depter Mukpo}

'Brong pa rgyal po. 2003. Bod ljongs mdo khams nang chen spyidang bye brag gi byung ba brjod pa ldong 'brong pa'i deb gter smug po (The General and Specific History and Presentation of the Tibetan Khampa Nangchen Kingdom; the Maroon Annals of the Dong Drong Clan). Dharamsala: Amnye Machen Institute.

\section{Gedrong Logyü}

Lho bstan 'dzin nyi ma. 2012. mDo khams dge 'brong lo rgyus deb ther lci zla'i zegs ma (Chronicle and Annals of the Good Khampa Drongpa Clan; Droplets of the Chichu and Dachu Rivers). Gan su: Gan su mi rigs dpe skrun khang.

\section{Gyelrap Ngotrö}

Ba ri zla ba tshe ring. 2005. Nang chen nyer lnga'i rgyal rabs ngo sprod dang lo rgyus rgyu cha'dems bsgrigs (Introduction to the Royal Chronicle of 
Nangchen and its Twenty-five Clans and their History; a Compilation of Selected Materials). Dharamsala, Nang chen nyer lnga'i mthun tshogs.

\section{Khamtö Logyü}

'Jam dbyangs tshul khrims. 1995-1997. Khams stod kyi lo rgyus thor bsdus su bkod pa gangs phrug bsu ba'i shing rta. The Brief History of Upper Kham, Eastern Tibet (Brief Registry of the History of Upper Kham; Chariot Welcoming Children of the Snowland). 2 Vols. Zi ling: Kan su'u mi rigs dpe skrun khang.

\section{Kyodrak Shedra}

sKyo brag bshad grwa. N.d. Chos rje skyo brag pa'i gnas dang bla ma rten gyi rnam thar mdor bsdus skal bzang dwangs pa'i dpal gter rin chen gser gyi phreng ba (The Abbreviated Hagiographic Account of How the Dharma Lord Chodrakpa Relied on His Practice Venue and His Teachers, the Splendid Treasury of the Pure and Fortunate Age, the Golden Jewelled Garland). sKyo brag bshad grwa karma legs bshad chos gling.

\section{Nangchen Gyelrap}

Karma phrin las. 1965. Gangs ljongs mdo stod nang chen rgyal rabs dang 'brel ba'i lo rgyus phyogs bsdudya rabs rna rgyan (The Summary of Histories Related to the Royal Chronicle of Nangchen in Upper Kham, Land of Snows; the Noble Ear Ornament). n.l.: Lama Wangchen.

\section{Nangchen GönkhakJungwa}

sGa Karma don grub phun tshogs, ed. 1999. Khams sgom sde nang chen pa'i dgon khag rnams kyi byung ba phyogs bsgrigs rin chen sgrom brgya 'byed pa'i deb ther gser gyi lde mig (Collection on the Origins of Monasteries in Kham Nangchen, Realm of Meditators; the Chronicle Unlocking One Hundred Trunks Like a Golden Key). Skye dgu mdo: Nang chen rdzong srid gros rig gnas lo rgyus gzhung don khang.

\section{Western sources}

Adeu Rinpoche. 2011. Freedom in Bondage: The Life and Teachings of Adeu Rinpoche. Berkeley, CA: North Atlantic Books.

Beckwith, Christopher I. 1993. The Tibetan Empire in Central Asia: A History of the Struggle for Great Power among Tibetans, Turks, Arabs, and Chinese during the Early Middle Ages. Princeton, NY: Princeton University Press.

Casey, Edward S. 1987. Remembering: A Phenomenological Study. Bloomington, IN: Indiana University Press. 
Childs, Geoff. 2005. 'How to Fund a Ritual: Notes on the Social Usage of the Kanjur (bKa' 'gyur) in a Tibetan Village'. Tibet Journal 30 (2): 41-48.

Debreczeny, Karl. 2014. 'Imperial Interest Made Manifest: sGa A gnyan dam pa's Mahākāla Protector Chapel of the Tre-shod Maṇạala Plain'. In Trails of the Tibetan Tradition: Papers for Elliot Sperling, edited by Roberto Vitali, 129-166. Dharamsala: Amnye Machen Institute.

Germano, David. 1998. 'Re-membering the Dismembered Body of Tibet: Contemporary Tibetan Visionary Movements in the People's Republic of China'. In Buddhism in Contemporary Tibet: Religious Revival and Cultural Identity, edited by Melvyn C. Goldstein and Matthew Kapstein, 53-94. Berkeley: University of California Press.

Goldstein, Melvyn C. 1991. A History of Modern Tibet, 1913-1951: The Demise of the Lamaist State. Berkeley: University of California Press.

Grenard, Fernand. 1904. Tibet: The Country and Its Inhabitants. Translated by A. Teixeira de Mattos. London: Hutchinson \& Co.

Gruschke, Andreas. 2004. The Cultural Monuments of Tibet's Outer Provinces: Kham. Vol. 2. The Qinghai Part of Kham. Bangkok: White Lotus.

Harrell, Stevan, and Li Yongxiang. 2003. 'The History of the History of the Yi, Part II'. Modern China 29 (3): 362-396.

Holmes-Tagchungdarpa, Amy. 2010. 'Defining Peripheral Power: Writing the History of the Kingdom of Lhathog, Eastern Tibet'. In New Views of Tibetan Culture, edited by David Templeman, 7-19. Caulfield, Australia: Monash University Press.

Litzinger, Ralph A. 1998. 'Memory Work: Reconstituting the Ethnic in Post-Mao China'. Cultural Anthropology 13 (2): 224-255.

Marshall, Steven D., and Susette Ternent Cooke. 1997. Tibet Outside the TAR: Control, Exploitation and Assimilation: Development with Chinese Characteristics. Washington, DC: Alliance for Research in Tibet.

McGranahan, Carole. 2010. Arrested Histories: Tibet, the CIA, and Memories of a Forgotten War. Durham, NC: Duke University Press.

Oosten, Jarich G. 1988. 'The Stranger-King. A Problem of Comparison'. In Time Past, Time Present, Time Future: Perspectives on Indonesian Culture: Essays in Honour of Professor PE de Josselin de Jong, edited by Henri J.M. Claessen and David S. Moyer, 259-275. Dordrech: Foris Publications (Verhandelingen van het Koninklijk Instituut voor taal. Landen Volkenkunde, 131).

Petech, Luciano. 2003. 'The Establishment of the Yuan-Sa-skya Partnership'. In The History of Tibet, edited by Alex McKay. London: Routledge Curzon.

Prins, Marielle. 2007. 'The Rgyalrong New Year: A Case History of Changing Identity'. Zentralasiatische Studien 36: 189-216.

Rafael, Vicente L. 1999. 'Regionalism, Area Studies, and the Accidents of Agency'. American Historical Review 104 (4): 1208-1220. 
Ramble, Charles. 2008. The Navel of the Demoness: Tibetan Buddhism and Civil Religion in Highland Nepal. New York: Oxford University Press.

Rowlands, Michael. 1993. 'The Role of Memory in the Transmission of Culture'. World Archaeology 25 (2): 141-151.

Sahlins, Marshall. 2008. 'The Stranger-King or, Elementary Forms of the Politics of Life'. Indonesia and the Malay World 36 (105): 177-199.

Sahlins, Marshall and David Graeber. 2017. On Kings. Chicago: Hau Books.

Scott, James C. 1990. Domination and the Arts of Resistance: Hidden Transcripts. New Haven, CT: Yale University Press.

Schwieger, Peter. 2009-2010. 'Significance of Ming Titles Conferred upon the Phag mo gru Rulers: A Reevaluation of Chinese-Tibetan Relations during the Ming Dynasty'. The Tibet Journal 34/35 (3/2): 313-328.

Shakabpa, Tsepon Wangchuk Deden. 2010. One Hundred Thousand Moons: An Advanced Political History of Tibet. Vol. 1. Translated by Derek F. Maher. Leiden: Brill.

Sørensen, Per K. 2015. 'The Development and Formation of religious Historiography in Tibet'. In History and Religion. Narrating a Historical Past. Religionsgeschichtliche Versuche und Vorarbeiten, edited by Otto Bernd-Christian, Suanne Rau and Jörg Rüpke, 151-164. Berlin: De Gruyter.

Sperling, Elliot. 2003. 'Introduction' to Bod ljongs mdo khams nang chen spyi dang bye brag gi byung ba brjod pa ldong 'brong pa'i deb gter smug po, by 'Brong pa rgyal po, 7-37. Dharamsala: LTWA.

Tafel, Albert. 1914. Meine Tibetreise: Eine Studienfahrt durch das Nordwestliche China und durch die Innere Mongolei in das Östliche Tibet. Vol. 2, Stuttgart: Union Deutsche Verlagsgesellschaft.

Tambiah, Stanley J. 1976. World Renouncer and World Conqueror. A Study of Buddhism and Polity in Thailand against a Historical Background. Cambridge: Cambridge University Press.

Tsomu, Yudru. 2006. Local Aspirations and National Constraints: A Case Study of Nyarong Gonpo Namgyel and His Rise to Power in Kham (1836-1865). Unpublished PhD dissertation, Harvard University.

Tulku Urgyen. 2005. Blazing Splendor: The Memoirs of the Dzogchen Yogi Tulku Urgyen Rinpoche, as Told to Erik Pema Kunsang \& Marcia Binder Schmidt. Translated by Erik Hein Schmidt and Marcia Binder Schmidt. Kathmandu, Nepal: Rangjung Yeshe Publications.

Turek, Magdalena Maria. 2018. 'The Contemporary Revival of the Barom Kagyü School in Kham'. In The Hybridity of Buddhism: Contemporary Encounters between Tibetan and Chinese Traditions in Taiwan and the Mainland, edited by Fabienne Jagou, 133-158. Paris: École française d'Extrême-Orient.

Turek, Magdalena Maria. Forthcoming a. 'Monastic Obligations, Hat Change and Lhasa Encroachment: Notes on the Economic System in the Historical Kingdom 
of Nang-chen'. In When the Taxman Cometh: Tax, Corvée and Community Obligations in Tibetan Societies, edited by Charles Ramble, Peter Schwieger, and Alice Travers. Leiden: Brill.

Turek, Magdalena Maria. Forthcoming b. 'Milarepa in a People's Commune: Myth and Charisma in Contemporary Tibetan Hagiography and Society'. In Re-remembering Early Contact between Tibetans and the Chinese Communist Party in the post-Mao Period, edited by Robert Barnett, Françoise Robin, and Benno Weiner. Leiden: Brill.

Tuttle, Gray. 2015. 'An Overview of Amdo (Northeastern Tibet) Historical Polities'. The Tibetan and Himalayan Library Online. http://www.thlib.org/reference/ dictionaries/tibetan-dictionary/about/wiki/an\%2ooverview\%20of\%20amdo20. Accessed 15 October 2015 .

Vitali, Roberto. 1990. Early Temples of Central Tibet. London: Serindia Publications. Walter, Michael L. 2009. Buddhism and Empire: The Political and Religious Culture of Early Tibet. Leiden: Brill.

Weiner, Benno Ryan. 2012. The Chinese Revolution on the Tibetan Frontier: State Building, National Integration and Socialist Transformation, Zeku (Tsékhok) County, 1953-1958. Unpublished PhD dissertation, Columbia University.

\section{About the Author}

M. MARIA TuREK received her PhD in Tibetan Studies at the Humboldt University of Berlin in 2013. Her work centres on the practice of Tantric Buddhism among Tibetans living in the People's Republic of China and on sacred kingship in Eastern Tibet as represented in the contemporary historiographies published within China and in the Tibetan diaspora. She is currently affiliated with the Robert H.N. Ho Centre for Buddhist Studies at the University of Toronto, where she teaches courses on global Buddhism. Her current project is a book entitled Sainthood and Asceticism in an Eastern Tibetan Hermitage. It is an ethnographic study of ascetics devoted to traditional Tantric meditation practices in ritual seclusion revived within China today. 